\title{
DE CIVIELE MAATSCHAPPIJ: EEN 'NIEUWE' PARTNER IN EEN 'OUD' SYSTEEM?
}

\section{Thomas Vervisch}

Department of Philosophy and Moral Science

Ghent University

Blandijnberg 2

9000 Gent

Belgium

e-mail: thomas.vervisch@ugent.be

\section{SUMMARY}

\section{Civil Society in Africa: A 'new' partner in an 'old' system?}

Since the 1990s, there has been a growing consensus in the international development community about the role of civil society as a relevant partner in economic development and political change all over the world. This article places this debate in the context of statesociety relations in Sub-Sahara-Africa. As will become clear, the international consensus is based on one specific and highly normative interpretation of this relation between state and civil society. This consensus defines civil society as an independent actor vis-à-vis the state, capable of championing democratic and governance reforms. Our own argument starts from the assumption that this interpretation ignores the complex interrelatedness of state and civil society in African societies. As such, we propose a theoretical framework that recognizes a plurality of different state-society relations and also pays 
attention to informal as well as formal relations between state and civil society. By doing so, we question the international consensus about the role civil society can play in Sub-Sahara-Africa.

Key Words: Civil Society, State-Society Relations, Sub-Sahara-Africa

\section{INLEIDING}

Sinds het begin van de jaren negentig bestaat binnen de internationale gemeenschap een duidelijke consensus dat de civiele maatschappij een relevante partner is om het hoofd te bieden aan de economische en politieke crisissen in Sub-Sahara-Afrika en in ontwikkelingslanden in het algemeen (Bratton, 1989a; Bratton \& van den Walle, 1992; Edwards \& Foley, 1996; Edwards \& Hulme, 1996; Clayton, 1997; Fowler, 2000; Mercer, 2002; Van Rooy, 1998; Howell \& Pearce, 2001; Tvedt, 1998; Diamond, 1994; Harbeson, Rothchild \& Chazan, 1994). Zowel in het noorden als in het zuiden heeft dit verschillende gevolgen op beleidsniveau.

In het noorden wordt vanaf het begin van de jaren negentig de ondersteuning van deze civiele maatschappij een belangrijke pijler in de bilaterale samenwerking van donorlanden (DFID, 2006) met de programma's van de multilaterale instellingen (Wereldbank, 2005; EU, 2000; UNDP, 2003). Deze focus op de civiele maatschappij vertaalt zich in een grotere aandacht voor de rol van niet gouvernementele organisaties (NGO's). De civiele maatschappij wordt in zekere zin gelijkgesteld met deze NGO's. Omwille van hun democratisch en participatief karakter worden ze beschouwd als de ideale actoren om de civiele maatschappij in ontwikkelingslanden te ondersteunen (Mercer, 2002).

Het percentage van fondsen door staten toegekend aan deze NGO's, in het kader van hun bilaterale ontwikkelingshulp, blijft dan ook stijgen. Edwards en Hulme (1996: p. 962) halen globale cijfers aan voor de lidstaten van de Organisation for Economic Co-operation and Development (OECD). Hun percentage van bilaterale ontwikkelingshulp gespendeerd via NGO's steeg van 0,7 procent in 1975 naar 3,6 procent in 1985 en 5 procent in 1993-94. In 1993-94 betekende dit in absolute termen $\$ 2,3$ miljard. Volgens de cijfers van de OECD 
werd tien jaar later, in 2004, al $\$ 5$ miljard aan bilaterale ontwikkelingshulp gespendeerd via NGO's (OECD, 2006).

Voor de multilaterale ontwikkelingshulp geldt dezelfde stijgende tendens. Multilaterale instellingen zoals de Internationale Financiële Instellingen (IFI's), het Internationaal Monetair Fonds, de Wereldbank en de regionale ontwikkelingsbanken werken meer dan vroeger met en via NGO's. De Wereldbank (2005: p. 18) kent een gestage toename van projecten die geïmplementeerd en gefinancierd worden via NGO's. Deze toename geldt ook voor de Europese Unie (EU, 2000) en voor verschillende VN-organisaties, zoals United Nations Development Program (UNDP, 2003).

In dit opzicht waarschuwen Edwards en Hulme voor een groeiende afhankelijkheid van overheidssubsidies in hoofde van individuele NGO's (Edwards \& Hulme, 1996). Ze geven het voorbeeld van de vijf grootste NGO's in Groot-Brittannië die hun graad van afhankelijkheid van overheidssubsidies zagen toenemen van 7 tot 15 procent midden jaren 1980, naar 18 tot 52 procent in 1994. In Noord-Amerika en andere Europese landen liggen deze percentages nog hoger. Zowel in Scandinavische landen als in Canada lopen deze percentages op van 50 tot 90 procent.

Verder bespreken Edwards en Hulme (1996) nog de gevolgen voor het zuiden. Door de stijgende interesse van donorlanden voor het financieren van NGO's, wordt er vanaf de jaren 1990 een behoefte gecreëerd aan 'civiele' afnemers van deze financiering in de ontwikkelingslanden zelf. Ze geven het voorbeeld van Nepal waar het aantal NGO's steeg van 220 in 1990 naar 1210 in 1993. Fowler (1991) beschrijft eenzelfde trend in Afrika en zowel hij als Hearn (1999) leggen het verband tussen de veranderde wijze van financiering en de opkomst van civil society organizations (CSOs) in de meeste Afrikaanse landen.

Hoewel er verschillen bestaan in het beleid van bilaterale en multilaterale donoren, valt de algemene tendens toch op: "In the past 10 years, as a matter of policy, most official donors have included and expanded the 'civic channel' as intermediary for, and direct targets of, their assistance" (Fowler, 2000: p. 5). Van de civiele maatschappij wordt blijkbaar verwacht dat ze een rol speelt in de opkomst en consolidering van democratische regimes en dat zij een belangrijke partner wordt in het good governance beleid. 
Dit artikel situeert deze verwachtingen van de internationale gemeenschap over de rol van de civiele maatschappij in de context van Sub-Sahara-Afrika. Kan de civiele maatschappij in Sub-SaharaAfrika de verwachtingen van de internationale gemeenschap inlossen? Deze vraag kan niet worden beantwoord zonder te verwijzen naar de relatie tussen de civiele maatschappij en de staat. Een analyse van deze relatie in Sub-Sahara-Afrika dringt zich bijgevolg op.

In een eerste deel wordt aangetoond dat de internationale consensus omtrent de rol van de civiele maatschappij gestoeld is op één specifieke invulling van deze relatie tussen staat en civiele maatschappij. Van de civiele maatschappij wordt verwacht dat ze een autonome kritische waakhondfunctie vervult. Een verklaring voor deze consensus vindt men in de historische processen die geleid hebben tot de opkomst van wat we het civiele maatschappijparadigma noemen, en in de theoretische veronderstellingen die dit paradigma onderbouwen.

In een tweede deel verplaatsen we onze focus naar Sub-Sahara-Afrika. We wijzen op het feit dat deze consensus de dynamische interactie tussen staat en civiele maatschappij in Sub-Sahara-Afrika negeert. We stellen een conceptueel kader voor dat de verscheidenheid aan relaties tussen staat en civiele maatschappij in Sub-Sahara-Afrika erkent, en tevens ook rekening houdt met informele naast formele relaties tussen beide.

Op basis van een literatuurstudie over de rol van de civiele maatschappij in Sub-Sahara-Afrika werken we in een derde deel dit conceptueel kader verder uit.

\section{DE OPKOMST VAN HET 'CIVIELE MAATSCHAPPIJ-PARADIGMA'}

De visie van de United States Agency for International Development (USAID) vat de consensus omtrent de rol van de civiele maatschappij bij de internationale gemeenschap kernachtig samen: "Civil society' is defined as nonstate organizations that can (or have the potential to) champion democratic/governance reforms" (Hansen, 1996: p. 13). Maar waar komt deze consensus vandaan? 


\subsection{Historische Processen}

Vooreerst is de rol die men toekent aan de civiele maatschappij in het algemeen gebaseerd op een historische analogie met de rol die de civiele maatschappij speelde in Oost-Europa bij de val van het communisme (Arato \& Cohen, 1992: p. 29-89). Toen in 1989 de Sovjetunie uit elkaar viel, was dit mede veroorzaakt door sociaal protest in landen zoals Polen, Tsjecho-Slowakije, Hongarije en OostDuitsland (DDR). Het bekendste voorbeeld blijft de sociale beweging Solidarnosc die in 1989, na jaren van geweldloos verzet, bijdroeg tot het omverwerpen van het communistische regime in Polen (Arato, 1981; Bialecki \& Heyns, 1991).

Deze vorm van verzet tegen totalitaire regimes in grote delen van Oost-Europa werd door de leiders van het verzet, maar ook in academische kringen, al snel beschouwd als de eerste tekenen van een nieuw ontstane civiele maatschappij (Lovell, 1999; Butterfield \& Weigle, 1992; Rau, 1991; Glenn, 2001; Arato \& Cohen, 1992). De civiele maatschappij in deze delen van Oost-Europa ontstond bijgevolg uit de strijd tegen de totalitaire staat en werd gedefinieerd als een alternatief op deze staat: "The opposition of civil society and state made its most dramatic return in East Europe. [...] The idea was always the protection and/or self-organization of social life in the face of the totalitarian or authoritarian state" (Arato \& Cohen, 1992: p. 31 ). Het verzet werd dan ook beschreven als anti-politics (Pietryk, 2003).

Het was dit verzet in delen van Oost-Europa dat op het einde van de twintigste eeuw de civiele maatschappij opnieuw onder de aandacht bracht (Arato \& Cohen, 1992). Naar analogie met deze specifieke context van duidelijke strijd tussen staat en civiele maatschappij in delen van Oost-Europa werd de civiele maatschappij in andere delen van de wereld eveneens gedefinieerd vanuit haar strijd tegen de staat, alsof de historische context van Oost-Europa begin jaren 1990 een universeel gegeven was (Arato \& Cohen, 1992; Mercer, 2002; Baker, 1998).

Een tweede verklaring voor de algemene consensus binnen de internationale gemeenschap over de rol van de civiele maatschappij ligt in de opkomst van de good governance-agenda. Vooral de Wereldbank plaatste begin jaren 1990 good governance als een 
belangrijk thema op de agenda van de internationale gemeenschap. Hoewel dit good governance-beleid van de Wereldbank toen en ook vandaag nog op alle ontwikkelingslanden van toepassing is, geldt dit beleid in het bijzonder voor Sub-Sahara-Afrika (Williams \& Young, 1994).

Vanaf het begin van de postkoloniale periode tot het einde van de jaren 1980 hadden Afrikaanse landen gemeen dat ze de staat een centrale rol toebedeelden op vlak van economische ontwikkeling: "The state was to pull the whole society along in an all-out development drive on several fronts" (Doornbos, 1990: p. 182). Met de economische crisis van de jaren zeventig werd echter duidelijk dat Afrika de strijd tegen onderontwikkeling aan het verliezen was (World Bank, 1989). Dit leidde tot een ommekeer in het denken over de rol van de staat op het Afrikaanse continent: "In case after case, high expectations were followed by profound disillusionment, and the role attributed to the African state changed from the prime mover of development to that of its main obstacle" (Doornbos, 1990: p. 183). Vanaf dat moment werd de crisis in Afrika vooral onder invloed van het IMF en de Wereldbank omschreven als een crisis of governance (Williams \& Young, 1994).

Samen met de val van de Berlijnse muur, die de steun aan bepaalde Afrikaanse regimes in het Koude Oorlog tijdperk stil legde, zorgde deze analyse ervoor dat de staatsgeoriënteerde visie op ontwikkeling bij donorlanden in het westen vervangen werd door een doorgedreven marktgeoriënteerde visie. Verder was de internationale gemeenschap begin jaren 1990 in de ban van de nieuwe aid conditionality. Externe hulp werd van dan af gekoppeld aan politieke voorwaarden, waarvan goed bestuur en democratisering de kern vormden (Thomson, 2000: $\mathrm{p}$. 143-154).

Dit good governance-beleid leidde eind jaren tachtig tot de omstreden Structural Adjustment Programs (SAPs) die Afrikaanse landen dwongen te privatiseren en hun sociale voorzieningen af te bouwen. Maar het was tevens in dit kader dat de civiele maatschappij opnieuw naar voren trad. Volgens de analyse van de Wereldbank hadden Afrikaanse landen tevens een 'pluralistische institutionele structuur' nodig die de staat opnieuw politieke legitimiteit en slagkracht zou verschaffen. De civiele maatschappij zou hier volgens hen een belangrijke rol moeten in spelen: "strong civil society organizations 
can promote the politicai empowerment of poor people, pressuring the state to better serve their ir.terests and increasing the effectiveness of antipoverty programs" (World Bank, 2000: p. 114).

Het centraal stellen van de waakhondfunctie van de civiele maatschappij moet gezien worden in het licht van dit good governance-beleid: "The Bank's promotion of civil society is linked to its promotion of accountability, legitimacy, transparency and participation as it is these factors which empower civil society and reduce the power of the state" (Williams \& Young, 1994: p. 87). Het belang van de civiele maatschappij wordt bijgevolg in grote mate bepaald door de eis om tot een efficiënt, transparant en legitiem beleid te komen. Van de civiele maatschappij wordt verwacht om over dit proces te waken.

Bij de overgang van de SAPs naar de Poverty Reduction Strategy Papers (PRSPs) eind jaren negentig werd deze waakhondfunctie nog duidelijker. Deze PRSP is tot op vandaag één van de belangrijkste beleidsdocumenten binnen het beleid van de Wereldbank. Dit document geeft het beleid van armoedebestrijding van een bepaald land weer, en wordt beschouwd als de meer 'humane' opvolger van de SAP. Het wordt opgesteld door de regering van het land zelf en is een voorwaarde tot schuldvermindering binnen het kader van het HIPC (Highly Indebted Poor Countries) Initiatief.

McGee (2003) wijst voor de civiele maatschappij op de overgang van een dienstverleningsfunctie (SAPs) naar een waakhondfunctie (PRSPs). Als gevolg van opgelegde privatiseringen, doorgevoerd tijdens de SAPs, werden de sociale voorzieningen van de staat afgebouwd. Vele "civiele maatschappij-actoren" hebben toen de dienstverleningsfunctie van de staat op zich genomen. Bij de PRSP moet de civiele maatschappij in eerste instantie niet meer zelf instaan voor bijvoorbeeld toegang tot gezondheidszorg (dienstverleningsfunctie), maar wordt verwacht dat ze het gezondheidsbeleid van de regering opvolgt, controleert en bijstuurt (waakhondfunctie). Bijgevolg verwacht de Wereldbank een volwaardige participatie en consultatie van de civiele maatschappij bij het opstellen van de PRSP. Dit toont tevens aan dat de waakhondfunctie samenwerking tussen staat en civiele maatschappij niet uitsluit. Het betekent echter wel dat er wordt uitgegaan van een autonome civiele maatschappij met een zekere legitimiteit. Op basis van deze autonomie en legitimiteit moet 
de civiele maatschappij in de eerste plaats de staatsmacht controleren en aansprakelijk houden, en dit in functie van het good governancebeleid.

Een derde verklaring voor de algemene consensus binnen de internationale gemeenschap over de rol van de civiele maatschappij, maar dan specifiek voor Sub-Sahara-Afrika, zijn de democratiseringsprocessen die zich in de jaren negentig voordoen op het Afrikaanse continent. Het aantal Afrikaanse landen met een meerpartijenstelsel steeg van 9 in 1988 tot 45 in 1999 (Thomson, 2000: p. 216). In vele landen werd deze democratiseringstendens niet geconsolideerd. Maar het geweldloos aftreden na verkiezingen van Kenneth Kuanda, 27 jaar president van Zambia, en de verkiezingsoverwinning van Nelson Mandela in Zuid-Afrika werden beschouwd als voorbeelden van wat Thabo Mbeki de politieke renaissance van Afrika noemde.

Naast het einde van de Koude Oorlog, de nieuwe aid conditionality voor westerse hulp en het failliet van de Afrikaanse staat werd de civiele maatschappij beschouwd als misschien wel de belangrijkste interne - factor die tot deze democratiseringsprocessen leidde (Thomson, 2000: p. 215-245). Het boek Civil Society and the State in Africa (Harbeson et al., 1994: p. 1-2) geeft goed het optimisme weer dat bestond over de rol die de civiele maatschappij kon spelen: "Today, grassroots movements have arisen in nearly every Sub-Saharan country to remove autocratic, repressive governments and empower African peoples to reclaim control over their political destinies" (Harbeson, 1994: p. 1-2). Het gevolg was een explosie van studies over de civiele maatschappij en de opkomst en consolidatie van democratie in Afrika (Thomson, 2000; Bratton \& van de Walle, 1992; Chabal, 1998; Mercer, 2002; Makumbe, 1998; Monga, 1995; Larmer, 2006; Harbeson, et al., 1994; Hearn, 2000; Kuperus, 1999).

Hoewel vele van deze studies het belang van de civiele maatschappij voor politieke en economische veranderingsprocessen in Afrika in vraag stellen, en er dus geen academische consensus bestaat in het debat over de rol van de civiele maatschappij in de democratiseringsprocessen op het Afrikaanse continent, wijst Gibson (2002: p. 213) op de eenzijdige impact van dit debat op de politieke realiteit: "Unlike many discussions within the academy, this one did influence the policy world. For a variety of reasons - not the least being the positive role allotted to civil society by political scientists' thinking - donor 
countries and IFIs quickly employed the concept in their decision over aid allocation." De reden waarom de critici in het debat veel minder gehoor krijgen, is duidelijk. Het optimisme over de mogelijke rol van de civiele maatschappij in democratiseringsprocessen kan gemakkelijk ingepast worden in het nieuwe beleid van de westerse landen en internationale instellingen: "Donors saw the concept of civil society as a convenient hat stand for ideas related to human rights, good government, participation, privatization, and public service reform" (Gibson, 2002: p. 213).

\subsection{Theoretische Veronderstellingen}

De algemene consensus rond de rol van de civiele maatschappij is ook gebaseerd op bepaalde theoretische veronderstellingen die, zoals we zullen aantonen, niet hard te maken zijn voor de Afrikaanse context. De eerste veronderstelling betreft de strikte scheiding tussen staat en civiele maatschappij, en bijgevolg het autonome karakter ervan. De plotse aandacht voor het concept van de civiele maatschappij begin jaren negentig, betekent niet dat het concept geen voorgeschiedenis heeft (zie hiervoor Arato \& Cohen, 1992). De eerste versie van het concept vinden we reeds terug bij Aristoteles. Hij spreekt van de politike koinonia of de politieke gemeenschap, later in het Latijn vertaalt als societas civilis. Aristoteles' concept verschilt evenwel grondig van de huidige invulling ervan, omdat Aristoteles nog geen onderscheid maakt tussen de staat en de maatschappij, tussen de polis en de oikos.

De strikte scheiding tussen de staat en de civiele maatschappij is bijgevolg ook niet aan de orde bij Aristoteles. Dit blijft zo tot in de zeventiende-achttiende eeuw. De opkomst van de moderne staten en het absolutisme in die eeuwen zorgt voor een nieuwe - moderne invulling van de civiele maatschappij. Arato en Cohen (1992) beschouwen Hegel als de eerste theoreticus van dit moderne concept van de civiele maatschappij. Wat het grondig doet verschillen van de traditionele invulling gebaseerd op het werk van Aristoteles, is dat er nu wel een strikte scheiding bestaat tussen de staat en de civiele maatschappij, die tevens aan deze laatste een autonomie verleent.

Het is deze theoretische veronderstelling, namelijk de scheiding tussen staat en civiele maatschappij, die vandaag de consensus over de rol 
van de civiele maatschappij in goed bestuur en democratie onderbouwt. Maar de vraag rijst of deze veronderstelling zomaar uit haar historische context kan worden getrokken: "A problem then emerges which is that the underlying structures necessary to the realization of liberal politics - to the autonomy or negative liberty of civil society on which these theorists want to build a democratising project - are actually particular in important ways to the historical experiences of the West, experiences which are not directly applicable elsewhere" (Baker, 1998: p. 85). Maar Baker gaat verder en wijst niet enkel op een historische maar ook op een normatief-specifieke invulling van deze scheiding tussen de staat en een autonome civiele maatschappij: "Indeed, the wider context necessary to this account of civil society could be construed as an apology for actually existing liberal democracy: 'politics' is to be put in its place, a private sphere is to be protected (relying, presumably, on the market for its 'independent' material base), and the state is to become - in this idealised vision - the neutral arbiter much beloved of liberal theory" (Baker, 1998: p. 83). Het is bijgevolg twijfelachtig of dezelfde historische context aanwezig is in Sub-Sahara-Afrika en of de normatieve invulling van deze scheiding tussen staat en autonome civiele maatschappij de Afrikaanse bevolking en hun leiders heeft kunnen overtuigen.

Wat Howell en Pearce (2001: p. 42-51) beschrijven als de Americanization of the Debate verklaart de tweede veronderstelling, namelijk de link tussen een actieve civiele maatschappij als voorwaarde voor een democratisch regime. Volgens hen is het hedendaagse debat over de civiele maatschappij in Afrika schatplichtig aan Alexis de Tocquevilles (1835/1840) studie van de democratie in Amerika op het einde van de negentiende eeuw. Hij kan worden beschouwd als de grondlegger van de tweede veronderstelling: "De Tocqueville's recognition of the importance of an active citizenship is one of his main contributions to the contemporary debate within liberal thought on the relationship between civil society and modern democracy" (Howell \& Pearce, 2001: p. 44). Dit idee wordt nog versterkt door wat de Neo-Tocquevillean revival wordt genoemd, en waar Robert Putnam een van de grondleggers van is.

Putnam (1993) onderneemt een poging om de hypothese van de Tocqueville empirisch te onderbouwen. In zijn studie analyseert hij 
het verband tussen democratische instituties en de aanwezigheid van een actieve civiele maatschappij in het noorden en zuiden van Italië. Zijn conclusie is de volgende: "Effective and responsive institutions depend, in the language of civic humanism, on republic virtues and practices. Tocqueville was right: Democratic government is strengthened, not weakened, when it faces a vigorous civil society" (Putnam, 1993: p. 182). In Bowling Alone (2000) maakt Putnam dezelfde analyse voor het hedendaagse Amerika. Hij schetst de tendens van een steeds minder actieve civiele maatschappij, en wijst hierbij op de gevaren die dit met zich meebrengt voor de Amerikaanse democratie. Putnams werk heeft een hele discussie met zich meegebracht in Amerika, die bijvoorbeeld werd uitgevochten in American Prospect, onder de naam The Tocqueville Files (Schudson, 1996; Putnam, 1996a en 1996b; Skocpol, 1996; Valelly, 1996; Galston, 1996; Landolt \& Portes, 1996).

Maar ook buiten Amerika heeft het werk van Putnam veel invloed. Het product van de civiele maatschappij noemt hij het sociaal kapitaal: "By 'social capital', I mean features of social life - networks, norms and trust - that enable participants to act together more effectively to pursue shared objectives" (Putnam, 1995: p. 664-665). Dit sociaal kapitaal beschouwt Putnam als de missing link om tot duurzame democratie en economische ontwikkeling te komen: "For political stability, for government effectiveness, and even for economic progress social capital may be even more important than physical or human capital" (Putnam, 1993: p. 183). Midden jaren 1990 wordt sociaal kapitaal dan ook een kernbegrip in het beleid van de Wereldbank en andere ontwikkelingsorganisaties. De Wereldbank richt het Social Capital Initiative op en publiceert een reeks documenten over het onderwerp (zie bijvoorbeeld Grootaert et al., 2004; Narayan, 1997). De Organisation for Economic Co-operation and Development (OECD) doet hetzelfde via het project Social capital: the challenge of international measurement (zie bijvoorbeeld Helliwell, 2002). Anderen, zoals Fukuyama (1995) en Knack en Keefer (1997), breiden de analyse van Putnam uit. $\mathrm{Zij}$ maken een vergelijkende analyse van landen en verklaren verschillen in economische vooruitgang en het democratisch karakter van regimes aan de hand van onder andere de sterkte van de civiele maatschappij. 
Het zijn beide theoretische veronderstellingen - de scheiding tussen civiele maatschappij en de staat, en het verband tussen een actieve civiele maatschappij en democratie - die aan de grondslag liggen van de consensus binnen de internationale gemeenschap over de civiele maatschappij als een kritische waakhond ten opzichte van de staat. Of zoals Mercer het verwoordt: "Most common is the allegiance to the normative ideal that civil society and NGOs are inherently 'good things'; microcosms of the (liberal) democratic process, comprised of the grassroots, both separate and autonomous from the state, while acting as a 'bulwark' against it" (Mercer, 2002: p. 9).

De vraag is nu of deze theoretische veronderstellingen opgaan voor de Afrikaanse realiteit. In wat volgt, wordt nagegaan hoe de civiele maatschappij zich kan verhouden tot de staat in Sub-Sahara-Afrika. Is er effectief een duidelijke scheiding tussen beide en kan de civiele maatschappij een rol spelen in de democratiseringsprocessen?

\section{DE AFRIKAANSE CIVIELE MAATSCHAPPIJ}

Vooraleer we kunnen nagaan welke rol de civiele maatschappij in Sub-Sahara-Afrika op zich neemt, moeten we eerst de inhoud van het begrip zoals totnogtoe gedefinieerd in vraag stellen. We hebben immers aangeduid dat de internationale gemeenschap de civiele maatschappij in grote mate gelijkstelt aan NGO's. Dat dit een verenging van het debat is, blijkt duidelijk wanneer we de vergelijking maken met de werkdefinitie van het Centre of Civil Society aan the London School of Economics and Political Science: "Civil society is the sphere of institutions, organisations and individuals located between the family, the state and the market, in which people associate voluntarily to advance common interests" (Anheier \& Helmut, 2002: p. 1). Deze definitie beperkt zich tot de gangbare onderverdeling van instituties, organisaties en individuen die vallen onder de noemer van de civiele maatschappij. Het is duidelijk dat het om veel meer gaat dan NGO's alleen, maar de definitie zegt niets over de relatie tussen de civiele maatschappij en de staat. In dit opzicht zijn er twee aanvullingen die relevant zijn voor de Afrikaanse context. Enerzijds wijzen we op de verschillende 'mogelijke' relaties tussen de 
staat en de civiele maatschappij. Anderzijds wijzen we op het belang van zowel formele als informele relaties tussen beide.

\subsection{Staat - Maatschappij-Relaties}

Wat Bayart (1986: p. 111) zegt over de civiele maatschappij in de Afrikaanse context vat goed de algemene consensus samen die we omschrijven in het eerste deel van dit artikel: "I shall define it provisionally as 'society in its relation with the state' ... in so far as it is in confrontation with the state." De relatie tussen staat en maatschappij is echter niet eenduidig te definiëren. Het conflictmodel, waar Bayart van uit gaat, doet - net zoals het harmonie-model volgens Bratton (1989a) afbreuk aan de complexiteit van die relatie. De post-koloniale periode lijkt eerder te wijzen op een dynamische spanning tussen staat en maatschappij waarbij complementariteit en antagonisme elkaar afwisselen (MacGaffey, 1994: p. 170). Volgens Bratton (1989a) is een conceptueel kader dat een continuüm veronderstelt tussen beide extremen - conflict en harmonie - een beter uitgangspunt. Azarya (1994) lijkt hiertoe een aanzet te geven wanneer hij incorporation tegenover disengagement plaatst. Bij incorporation zoekt de civiele maatschappij toenadering tot de staat om opgenomen te worden in haar netwerken en te kunnen delen in haar rijkdom. Bij disengagement echter neemt de civiele maatschappij zoveel mogelijk afstand van de staat om aan haar al of niet vermeende repressie te ontkomen. Wordt de focus verlegd van de maatschappij naar de staat, dan zijn incorporation en disengagement respectievelijk gekoppeld aan de consolidatie en contestatie van de staatsmacht. Azarya's (1994) concept van incorporation lijkt echter een te specifieke relatie te definiëren. Immers, een toenadering tussen staat en civiele maatschappij hoeft niet noodzakelijk te leiden tot de consolidatie van die staatsmacht. De civiele maatschappij kan deze tevens in vraag stellen. Azarya's (1994) concepten blijven steken in éénduidige relaties, namelijk incorporation als een complementaire en disengagement als een antagonistische relatie. Bratton (1989a) zelf stelt voor om incorporation te vervangen door engagement. Deze term is neutraler en kan gebruikt worden voor zowel harmonieuze als conflicterende relaties tussen staat en civiele maatschappij. Disengagement en engagement kunnen tevens gerelateerd worden aan 
de klassiek geworden concepten exit en voice van Hirschman (1970). Bratton (1989a) wil de concepten disengagement en engagement echter hanteren om zowel de initiatieven van de civiele maatschappij als die van de staat te beschrijven, wat niet het geval is bij de concepten exit en voice van Hirschman (1970). Uiteindelijk wil Bratton (1989a: p. 428) komen tot een ruimer conceptueel kader om de relaties tussen staat en maatschappij te analyseren: "We might, for example, be able to identify degrees of action from disengagement to engagement, whether initiated from state sources (to ignore, register, monitor, coordinate, co-opt, reorganize, or dissolve voluntary associations) or societal sources (to keep low profile, to fulfill bare legal requirements, to collaborate selectively with government, or to engage in policy advocacy)." In zijn artikel The Politics of Government-NGO Relations in Africa zet hij zelf een stap in deze richting (Bratton, 1989b). Dit artikel brengt echter meteen de zwakte van zijn analyse naar voor. Zijn invulling van de relaties tussen staat en maatschappij is eerder gebaseerd op zijn analyse van de relaties tussen NGO's en staten dan omgekeerd.

Een analyse zoals die van Bratton (1989b) verengt het debat snel tot de rol van NGO's in de civiele maatschappij. Deze NGO's worden beschouwd als de centrale actoren van de formele civiele maatschappij, namelijk die groepen, organisaties en associaties in de maatschappij die door de staat formeel erkend worden als zijnde vertegenwoordigers van de civiele maatschappij, en die bijgevolg tevens onder een legaal statuut werkzaam zijn. Maar de informele civiele maatschappij is in Sub-Sahara-Afrika even belangrijk als de formele.

\subsection{Formele en Informele Relaties}

Chazan (1982) betwist de these van political departicipation van de bevolking in Sub-Sahara-Afrika door te verwijzen naar het belang van informele politieke participatie van de bevolking op eerder lokaal niveau. In vele Afrikaanse landen lijkt er een onoverbrugbare kloof te bestaan tussen de bevolking en de staat. Maar volgens Chazan (1982) is deze kloof niet zo duidelijk. De afwezigheid van formele participatie - zoals via verkiezingen en politieke partijen - staat volgens deze auteur in schril contrast met de aanwezige informele participatie. Deze 
laatste krijgt vorm via allerlei organisaties en associaties met een zeer beperkte reikwijdte, maar die de bevolking toch in staat stellen tot interactie en participatie op lokaal niveau. Het is juist in deze informele participatie dat zich voor een groot stuk het actieveld van de civiele maatschappij situeert. Chazan (1982) brengt echter een onderscheid aan. Ze beschrijft twee groepen organisaties: "The first consists of voluntary organisations of an interest-group type... The second type of association is ascriptive, or primary, in essence" (Chazan, 1982: p. 172). Voorbeelden van de eerste groep zijn kerken en vakbonden, of vrouwengroepen die inkomensgenererende activiteiten gebruiken om hun gezamenlijke situatie te verbeteren. Etnische of familiale associaties zijn voorbeelden van de tweede groep.

Volgens Chazan (1982) onderscheiden beide types associaties zich van elkaar door het soort relaties waarop ze gebaseerd zijn. Het eerste type associaties zijn horizontaal georganiseerd en werken op basis van gemeenschappelijke belangen. $\mathrm{Zij}$ kunnen de formele civiele maatschappij worden genoemd. Deze organisaties hebben meestal een legaal statuut en worden bijgevolg door de staat erkend. Het zijn meestal ook deze organisaties die door internationale NGO's (INGO's) worden ondersteund. Ze vormen samen met de staat en de buitenlandse donoren de policy elite of policy community (Crook, 2001: p. 5). Het tweede type bestaat volgens Chazan (1982) uit verticaal georganiseerde associaties die via patroon-cliënt-netwerken etnische, familiale of regionale solidariteit promoten. Patroon-cliënt-netwerken kunnen gedefinieerd worden als een serie van verticale relaties die patroons met cliënten verbindt, waarbij de cliënt zelf als patroon een eigen netwerk van cliënten opbouwt (Thomson, 2000: p. 118). Deze organisaties bevinden zich eerder in de informele sfeer, hebben meestal geen legaal statuut, werken op lokaal niveau en worden bijgevolg ook minder opgemerkt door de INGO's.

Het is onwaarschijnlijk dat deze informele civiele maatschappij snel haar prominente rol in de Afrikaanse maatschappij zal verliezen, des te meer omdat de dagdagelijkse interacties onder de Afrikaanse bevolking veeleer via deze informele relaties verlopen (Woods, 1992: p. 94). Wat Chazan (1982) over de politieke participatie schreef, is bijgevolg evenzeer van toepassing op de civiele maatschappij: de informele civiele maatschappij is minstens even belangrijk als de formele. 
Maar Chazans (1982) scheiding tussen de formele en informele civiele maatschappij aan de hand van respectievelijk horizontale en verticale relaties is niet eenduidig. Verticale relaties worden evenzeer gebruikt binnen de formele civiele maatschappij (zie verder). Ook zijn niet alle informele associaties uitsluitend gebaseerd op verticale relaties. Wat men de informele civiele maatschappij noemt, omvat niet enkel etnische - of familiegroepen, maar evenzeer Community-Based Organizations (CBOs), die niet noodzakelijk gebaseerd zijn op etniciteit of familie, maar niettemin toch tot de informele civiele maatschappij behoren. Zowel eerder formele als informele civiele maatschappijorganisaties kunnen bijgevolg gebaseerd zijn op deze verticale relaties.

Niettemin, deze informele verticale relaties moeten geïntegreerd worden in ons concept van de Afrikaanse civiele maatschappij. MacGaffey (1994: p. 169) stelt voor om Brattons (1989b) analyse van NGO's als volgt uit te breiden: "I propose to look beyond such groups to explore the different kinds of networks of personal ties through which some individuals consolidate their advantageous positions and others engage in nonviolent, hidden, and everyday forms of resistance to oppressive conditions. " Het voordeel hiervan is dat het systeem van neo-patrimonialisme, dat gebaseerd is op deze verticale patrooncliënt-netwerken, op die manier in de analyse kan worden geïntegreerd. Bij patrimoniaal bestuur ligt de politieke autoriteit bij één individu en alle actoren binnen het politieke systeem danken hun positie aan hun loyaliteit tegenover de leider. Bij neo-patrimoniaal bestuur oefent de leider deze politieke autoriteit uit via de legaalrationele staatsinstituties. Patroon-cliënt-netwerken spelen een belangrijke rol om de loyaliteit tegenover de leider af te kopen (Thomson, 2000: p. 119; zie ook Hyden, 1997). Chabal en Daloz (1999: p. 21) zijn ervan overtuigd dat een analyse van politieke processen in Afrika niet aan dit neo-patromonialisme kan voorbijgaan: "... it is clear that the business of politics is more usually conducted along informal vertical channels of relations (patron-client networks, communal organizations, etc.)."

Bratton en van de Walle (1994) bijvoorbeeld, verklaren de politieke transities begin jaren negentig in Sub-Sahara-Afrika dan ook als een gevolg van het falen van dit systeem. Het neo-patrimonialisme zet echter vraagtekens bij een institutionalisering van de Afrikaanse staat 
naar Webers (1964) model van legaal-rationele staatsinstituties: "Neopatrimonialism exists in contemporary societies where the impact of the modern state has been felt, but where prevailing social norms make no such distinction between private and public realms" (Hyden, 1997: p. 25).

De verticale patroon-cliënt-netwerken verbinden high met low politics, respectievelijk de staat en de politieke elites met de rest van de bevolking (Chabal \& Daloz, 1999: p. 21). De link tussen high en low politics bestaat er in dat de elite deze netwerken gebruikt voor een herverdeling van economische bronnen - zoals bijvoorbeeld functies binnen de bureaucratie of concessies voor mijnontginning - op basis waarvan ze hun macht consolideren. In omgekeerde richting krijgt de bevolking via deze netwerken de mogelijkheid om te delen in de rijkdom van de staat in ruil voor haar loyaliteit. Dit systeem levert een verklaring voor de wisselende interpenetratie van staat en maatschappij: ze zijn via deze patroon-cliënt-netwerken organisch met elkaar verbonden.

Een voordeel van MacGaffeys (1994) analyse is dus dat ze tevens aandacht schenkt aan informele relaties wanneer ze de Afrikaanse civiele maatschappij beschrijft. Volgens MacGaffey (1994) kunnen deze relaties wel degelijk sociale bewegingen onderbouwen, zonder dat er sprake hoeft te zijn van een formalisering en institutionalisering. Deze interpersoonlijke relaties gebaseerd op etniciteit, familie of afkomst, die MacGaffey (1994) omschrijft als de social assets of the poor, kunnen net zoals de meer formele associatieve samenwerkingsverband en tot samenwerking leiden en vormen volgens haar een alternatief voor de civiele maatschappij. Hoewel ze eerder gebaseerd zijn op moreel-etnische dan op liberaal-democratische normen, doen patroon-cliënt-netwerken volgens Orvis (2001: p. 172) juist wat van de civiele maatschappij wordt verwacht: "Nonetheless, patron-client networks are informal groups that pursue their collective interests vis$\grave{a}$-vis the state, often retaining some autonomy from the state, and providing a means (however imperfect) of both political participation and accountability." In het licht van de vraag naar de rol van de civiele maatschappij op het Afrikaanse continent zal dit een te optimistische visie blijken, want dit soort relaties zijn gemakkelijk te exploiteren tijdens etnische conflicten en machtsconflicten in het algemeen, waar participatie en accountability ver zoek zijn. Het 
belang van deze informele relaties op het Afrikaanse continent mag niet worden onderschat, hoewel men vraagtekens kan plaatsen bij het democratische gehalte ervan.

\section{DE CIVIELE MAATSCHAPPIJ ALS TEGENMACHT?}

Op basis van de hierboven geschetste uitbreiding van het concept van de civiele maatschappij wordt nagegaan welke de mogelijke interacties kunnen zijn tussen de civiele maatschappij en de staat. Deze relaties die we plaatsen op het continuüm engagement/disengagement, vertonen eerder een formeel dan wel een informeel karakter en komen tot stand op initiatief van zowel de staat als de civiele maatschappij. Dit kader pretendeert niet exhaustief te zijn en dus niet alle mogelijke relaties komen aan bod. We menen echter wel dat dit conceptueel kader een betere analyse mogelijk maakt van de verschillende functies die de civiele maatschappij kan spelen in Afrikaanse landen.

\subsection{Formal Disengagement}

\section{DE STAAT}

Formal disengagement van staatswege betekent dat de staat zich terugtrekt uit haar formele relaties met haar burgers. Het falende optreden van een aantal Afrikaanse staten op het einde van de jaren tachtig is hier een voorbeeld van: "Across the continent, government services are breaking down or being cut back as authorities are unable to maintain or replace equipment, sustain a flow of consumable supplies, or even pay their personnel" (Bratton, 1989a: p. 410). De oorzaken van deze evolutie zijn veelvuldig, maar de economische crisis van de jaren zeventig, het structural adjustmentbeleid van de Wereldbank en het IMF, en het slecht bestuur van Afrikaanse staten zijn de meest bekende (Fatton, 1992).

Begin jaren negentig was de formele relatie tussen de staat en de burger in bepaalde Afrikaanse landen zo goed als onbestaande: bureaucratieën waren vergeven van corruptie, staatsapparaten werkten inefficiënt en vele van de sociale voorzieningen of andere diensten, indien ze al bestonden, werden afgeschaft. De bevolking had 
bijgevolg geen verwachtingen meer ten opzichte van de staat waar zij burger van was. Erger werd het wanneer de staat niet meer in staat was om zelfs haar militaire functie ter verdediging van haar burgers op te nemen of wanneer de staat helemaal niet meer aanwezig was in bepaalde gebieden van het land. Het Zaïre van Mobutu, met het gekende article 15, 'Débrouillez-vous', was omstreeks 1990 een duidelijk voorbeeld van gedeeltelijke of volledige formele 'terugtrekking' van de staat uit de maatschappij (MacGaffey, 1994: p. 182).

\section{De Civiele MaATSChaPPIJ}

Eén van de mogelijke reacties op dit falen van de staat kan eveneens formal disengagement zijn, maar dan vanuit de civiele maatschappij zelf. Formal disengagement betekent hier dat de civiele maatschappij zonder in interactie te treden met de staat systemen van zelfvoorziening opzet: "Throughout the 1980s and 1990s, civil society played an immensely important role in 'fillings the gaps' left by government in basic service provision" (Hearn, 2001: p. 50). Zowel internationale als lokale NGO's namen in deze periode de dienstverleningsfunctie over van de staat en werden op deze manier een substituut voor die staat.

Het is niet toevallig dat de grootste boom van NGO's in Afrika samenvalt met het structural adjustment-beleid. Van belang is dat de civiele maatschappij hiermee op een indirecte manier legitimiteit verschaft aan falende regimes (McGee, 2003). Dit doet ze door parallelle systemen op te zetten die het falen van de staat voor de bevolking verzachten. Op die manier gaat de civiele maatschappij geen confrontatie aan met de staat. Hearn (2001) beschrijft de situatie in Oeganda eind jaren 1980. Op dat moment was de sociale dienstverlening naar de Oegandese bevolking toe vooral in handen van de lokale en internationale civiele maatschappij. De redenen waren duidelijk: "This was crucial to both donors, given their obsession with the minimal state, and the government of Uganda, which needed to maintain a modicum of legitimacy" (Hearn, 200: p. 50). Bratton (1989b) beschrijft het voorbeeld van de kerken in onder andere Kenia en Zimbabwe die via hun missieposten over het hele land een parallel netwerk van sociale dienstverlening konden opzetten. De staat zal het conflict met deze civiele maatschappij dan ook niet snel opzoeken omdat de doelstellingen van beide com- 
plementair kunnen zijn. De staat is immers gebaat bij het overnemen van bepaalde van haar functies door de civiele maatschappij.

Een andere, soms vergeten, exit-strategie is migratie waarbij de formele relatie tussen burger en staat volledig wordt opgegeven. Azaryza en Chazan (1987) beschrijven deze vorm van disengagement in Ghana en Guinea. Een belangrijke groep van migranten zijn vooral de jonge werklozen die naar de buurlanden trekken op zoek naar seizoenswerk. Een heel andere groep zijn de hoger opgeleiden die in het buitenland gaan studeren en daar blijven. Een laatste groep zijn de politieke vluchtelingen. Deze laatste groep is een voorbeeld van hoe snel disengagement kan omslaan in engagement. In de jaren 1970 verbleven bijvoorbeeld een groot aantal Guinese politieke vluchtelingen in Senegal en Ivoorkust. Daar aangekomen, groepeerden ze zich in politieke bewegingen die later betrokken waren bij acties tegen de Guinese regering. Maar ook manipulaties van grote, meestal homogeen etnische, vluchtelingenpopulaties in Congo, Oeganda en Tanzania hebben in het Grote Merengebied al meermaals voor politieke instabiliteit gezorgd. Ook deze groepen kunnen beschouwd worden als een onderdeel van de civiele maatschappij, omwille van hun eis tot burgerschap - in de context van hun terugkeer naar het land van herkomst - en bescherming van minderheidsgroepen. Daar komt bij dat de terugkeer en rehabilitatie van deze vluchtelingenpopulaties als een zwaard van Damocles boven ieder democratiseringsproces hangen (Lemarchand, 1992).

Formal disengagement van zowel de staat als de civiele maatschappij heeft echter tevens te maken met een dieperliggend probleem. Volgens Chabal en Daloz (1999: p. 21) heeft de Afrikaanse staat nooit een proces van institutionalisering doorgemaakt: "The state is in fact so poorly institutionalized, so weakly emancipated from society, that there is very little scope for conceptualizing politics in Africa as a contest between a functionally strong state and a homogeneously coherent civil society." Hier komen we terug op het neo-patrimonialisme, want het zijn de informele patroon-cliënt-netwerken die deze institutionalisering onmogelijk maken, en die tevens de informele relaties tussen staat en civiele maatschappij kenmerken (Chabal \& Daloz, 1999: p. 17-30). Deze informele, verticale netwerken die de elites met de rest van de bevolking verbinden, zijn bijgevolg even belangrijk als de formele relaties tussen staat en maatschappij en 
vormen de basis voor wat informal disengagement kan worden genoemd.

\subsection{Informal Disengagement}

\section{DE STAAT}

Informal disengagement van de staat betekent dat de politieke elites zich terugtrekken uit hun informele verticale netwerken met de bevolking. Het falen van de staat is voor de bevolking bijgevolg niet alleen voelbaar via de beëindiging van de formele relaties tussen de staat en haar burgers, maar ook via de onmogelijkheid van de staat om haar informele netwerken met de bevolking te onderhouden. Chabal (1998: p. 292) is duidelijk: "The present African crisis, therefore, has its origins in the wholesale collapse of this neo-patrimonial system." Het neo-patrimonialisme is niet alleen slachtoffer maar tevens oorzaak van de economische crisis. Dit systeem maakt economische groei onmogelijk, en leidt bovendien tot een chronische fiscale crisis. Daar komt bij dat de herverdeling van economische bronnen door de politieke elites via het patroon-cliënt-systeem een uitsluiting op basis van etniciteit of afkomst van grote groepen van de bevolking kan impliceren. Bratton en Van de Walle (1994) beschrijven de ondergang van dit systeem in een groot aantal Afrikaanse landen als een perfecte voedingsbodem voor het sociale protest in het begin van de jaren negentig en verklaren bijgevolg de democratiseringsprocessen deels vanuit het failliet van dit systeem.

Zowel individuen als organisaties en associaties zijn afhankelijk van patroons binnen de politieke elite die instaan voor de herverdeling van staatsbronnen en jobs bij de overheidsinstellingen (Chabal, 1998: p. 292). Informal disengagement van de staat bestaat er dan in dat de politieke elites hun patroon-cliënt-netwerken niet meer kunnen onderhouden omwille van de schaarste aan economische bronnen. De staat trekt zich bijgevolg ook op een informele manier terug uit de samenleving.

Naast de mogelijkheid om via een formele weg de staat verantwoordelijk te stellen voor de economische en politieke crisis en politieke verandering te eisen, zal een groot deel van de bevolking echter opnieuw op zoek gaan naar nieuwe informele netwerken die van belang zijn voor hun dagdagelijkse levensonderhoud. 


\section{De Civiele MaATschapPiJ}

Informal disengagement betekent hier dat individuen, organisaties en associaties zich terugtrekken uit hun patroon-cliënt-netwerken en op zoek gaan naar andere informele relaties. Aanleiding kan zowel het opdrogen van deze netwerken zijn, alsook het extreem onderdrukkende karakter ervan. In beide gevallen is er een tendens tot grotere autonomie ten opzichte van de staat en is er dus sprake van disengagement. Informele parallelle systemen, meer dan de formele, bieden voor de bevolking een alternatieve strategie aan. Azarya en Chazan (1987: p. 121) beschrijven hiervan een aantal voorbeelden voor Ghana en Guinea: "Typical examples include black markets, smuggling, corruption, and the use of alternative methods of justice." Eén van de belangrijkste alternatieven op dit vlak is de informele of 'tweede' economie. Hoewel deze netwerken misschien de enige manier zijn om in het levensonderhoud te voorzien, leunt de informele economie dicht aan bij criminele netwerken en leidt het tot economische inefficiëntie en sociale ongelijkheid (MacGaffey, 1994: p. 183).

Niettemin is het niet enkel en alleen een vorm van levensonderhoud. De informele economie betekent tevens een vorm van samenwerking en leidt tot de uitbouw van informele netwerken. Op basis van informele, persoonlijke vertrouwensrelaties probeert men de afwezigheid van een functionerende staat te compenseren, en wordt een parallel systeem van waarden en normen, afspraken en regels opgebouwd. MacGaffey (1994) meent dat de these van James Scott (1987) in Weapons of the Weak over de vormen van verzet van boerenpopulaties, eveneens opgaat voor de informele economie.

De activiteiten in de informele economie kunnen opgevat worden als een alledaags verzet tegen de plunderende staat. Smokkelen wordt dan "an act of rebellion against the political and economic systems and the dominant groups" (MacGaffey, 1994: p. 174). Door het opzetten van dit parallel systeem trachten bevolkingsgroepen zich te beschermen tegen de rovende staat en verkrijgen ze een grotere controle en autonomie over de eigen strategieën van levensonderhoud. Zoals we later zullen zien, betekent dit niet dat de staat niet aanwezig is in de informele economie. Niettemin, naast een economisch alternatief geeft de informele economie ook een politiek signaal. 
De informele economie kan tevens een volledig alternatieve maatschappij met zich meebrengen, met parallelle informele sociale en religieuze instituties naast de officiële (Fatton, 1995). De implosie van het juridische systeem leidt tot nieuwe parallelle systemen gebaseerd op traditionele vormen van jurisdictie. Reno (2002) beschrijft bijvoorbeeld hoe jeugdgroepen zoals de Bakassi Boys in Oost-Nigeria het heft in eigen handen nemen en zelf afrekenen met misdadigers, waarbij ze op grote steun van de lokale bevolking kunnen rekenen. Meer algemeen kan er een populaire tegencultuur ontstaan die de antiestablishment gevoelens kanaliseert en concentreert.

\subsection{Formal Engagement}

\section{DE STAAT}

Formal engagement betekent dat de staat via formele kanalen toenadering zoekt tot de civiele maatschappij. De democratiseringsprocessen van begin jaren 1990 in een aantal Afrikaanse landen schetsen een goed beeld van hoe de staat de civiele maatschappij wenst te institutionaliseren. Wanneer organisaties binnen de civiele maatschappij te prominent worden en vooral wanneer hun agenda gepolitiseerd wordt, zullen conflicten met de staat ontstaan. Hierbij komen economische tegenover politieke motieven te staan. Regimes zijn bereid de externe financiële stromen die via de civiele maatschappij het land binnenkomen op te geven in functie van hun politieke stabiliteit. Op dat moment kunnen regimes op verschillende manieren reageren op de opkomende civiele maatschappij. Hier komt Brattons (1989b) analyse van de relaties tussen NGO's en staten van pas omdat hij een analyse maakt van de civiele maatschappij die op een formele manier in interactie treedt met de staat.

Kenmerkend voor alle vormen van toenadering tussen staat en civiele maatschappij is de drang tot controle. Ten eerste kan de staat optreden als monitor. Via registratie en rapportering kunnen staten de civiele maatschappij in kaart brengen om hun activiteiten op te volgen en te controleren. Een tweede optie is het optreden als coördinator. Onder het mom van efficiënt beleid verdedigt de staat haar interventie, zowel om de activiteiten in de civiele maatschappij onderling te stroomlijnen als om deze af te stemmen op het overheidsbeleid. Hoewel dit positieve gevolgen kan hebben, leidt het meermaals tot een averechts 
effect: een te gecentraliseerd en bureaucratisch beslissingsproces. Daar komt bij dat de autonomie van de civiele maatschappij duidelijk aangetast wordt. Bij een ergere vorm van dit laatste spreken we van coöptatie: "a firmer form of control in which autonomous organizations are captured and guided by a superordinate agency" (Bratton, 1989b: p. 579). Staten maken in dit stadium gebruik van quangos (quasi-NGO's): door de staat gesponsorde NGO's die onder de bevoegdheid vallen van een ministerie. Effectieve incorporatie kan ook; dan worden autonome organisaties geïncorporeerd in de staatsstructuren. Het 'no-party' presidentialisme, zoals in 1986 door Museveni in Oeganda geïnstalleerd, was er op gericht alle groepen in de civiele maatschappij in één partij onder te brengen zodat oppositie van in het begin onmogelijk werd (Crook, 2001: p. 8). Dit was trouwens een beproefde methode in vele Afrikaanse landen waar een één-partij-regime aan de macht was.

De meest extreme vorm van overheidscontrole komt voor wanneer de civiele maatschappij ontbonden wordt. Deze reactie komt niet zoveel voor en hangt vooral af van hoe sterk de civiele maatschappij zelf is. Indien de civiele maatschappij sterk genoeg staat, kan het ontbinden ervan het tegengestelde effect geven.

\section{DE Civiele MaATSCHAPPIJ}

Formal engagement betekent hier de manier waarop organisaties en associaties via formele weg trachten in relatie te treden met de staat. Er zijn verschillende manieren waarop de civiele maatschappij met de staat kan onderhandelen.

Een eerste optie is wanneer organisaties opteren voor een low profilestrategie. Zeker organisaties die werken rond delicate onderwerpen zoals mensenrechten of sociale rechtvaardigheid zijn hierbij gebaat. Het Public Law Institute (PLI), opgericht in 1981 door de National Council of Churches of Kenya (NCCK) and the Law Society of Kenya (LSK), is één van de vele mensenrechtenorganisaties in Kenia. In 1990 werd het instituut geregistreerd als een erkende NGO. Hoewel het PLI zich profileert als een mensenrechtenorganisatie nam ze veelal een low profile-strategie aan door zich te focussen op minder delicate items zoals consumentenrechten en de milieuproblematiek. Op die manier treedt ze niet in directe confrontatie met de staat (Bratton, 1989b: p. 581). 
Een tweede optie is om selectief samen te werken. Dit gebeurt wanneer de belangen van beide actoren complementair zijn. Organisaties hebben er soms baat bij - of zijn in sommige gevallen zelfs genoodzaakt - om terug te vallen op overheidsstructuren. Financiële belangen zijn meestal de doorslaggevende factor. Indien de staat al fondsen ter beschikking stelt dan worden deze verdeeld via de quangos of die organisaties die samenwerken met de staat. Zeker nu het partnership-model tussen de staat en de civiele maatschappij opgang maakt bij internationale instellingen zoals de Wereldbank kunnen NGO's via de overheid contracten in de wacht slepen (Hearn, 2001). Dit beleid van sub-contracting leidt opnieuw tot het gevaar van een civiele maatschappij die eerder het beleid van de staat - en dat van de internationale instellingen - legitimeert, in plaats van een kritische waakhondfunctie op zich te nemen.

De situatie waarin de civiele maatschappij via advocacy-taken het beleid tracht te beïnvloeden, is dan een derde optie, die echter in praktijk zeer moeilijk haalbaar is. Het is immers een evenwichtsoefening tussen enerzijds het behoud van autonomie en anderzijds een effectief partnerschap dat kan leiden tot beleidsbeïnvloeding.

Deze verschillende strategieën kunnen elkaar afwisselen of elkaar opvolgen. Ndegwa (1994) beschrijft bijvoorbeeld hoe de Keniaanse civiele maatschappij de verschillende opties doorlopen heeft in haar strijd tegen de NGO-wetgeving. In 1990 introduceerde de Keniaanse regering de nieuwe $N G O$ coordination bill, die als doel had om de aanwezige NGO's beter te controleren. NGO's werden verplicht om hun budgetten en projecten te laten goedkeuren door een centraal bureau van de overheid. Al snel hebben de NGO's deze nieuwe wet aangevochten, waarbij ze de verschillende stappen hebben doorlopen: "The above case suggests that societal organizations are not conditioned to automatically repel state intimidation. Instead, the process unfolds in stages from attempts to adjust to repression, to lobbying the government in non-threatening ways, and eventually, where conditions permit, to outright challenges against repression" (Ndegwa, 1994: p. 32).

Formal engagement van de civiele maatschappij kan echter ook meer verregaande vormen aannemen. Hierbij wordt de civiele maatschappij ingeschakeld in politieke transitieprocessen en neemt ze zelf deel aan het politieke machtsspel. Zambia is hiervan een goed en geslaagd 
voorbeeld (VonDoepp, 1996). Het populaire verzet tegen het regime van Kuanda werd geleid door de kerken en vooral de Zambian Congress of Trade Unions (ZCTU) onder leiding van Chiluba. Hoewel het regime van Kuanda meermaals pogingen ondernam om deze sterkhouders van de civiele maatschappij te infiltreren en te coöpteren, moest het in 1990 overgaan tot politieke liberalisering en liet het nieuwe politieke partijen toe. Chiluba, presidentskandidaat van de Multiparty Democracy (MMD), werd in oktober 1991 effectief verkozen tot president. Dit toont aan dat engagement vanwege de civiele maatschappij niet stopt waar de effectieve politieke macht begint.

De situatie waarbij de civiele maatschappij een evenwicht behoudt tussen haar autonomie en effectieve beleidsbeinnloeding leunt het dichtst aan bij het ideaal van de civiele maatschappij als de waakhond van de staat. De internationale consensus omtrent de civiele maatschappij als promotor van democratie en goed bestuur hoort dan ook thuis onder wat we hier formal engagement noemen. Tweemaal wordt deze consensus echter in vraag gesteld. Ten eerste, blijken er binnen de formal engagement relaties een aantal problemen op te duiken. Het aannemen van een low profile-strategie, de praktijk van subcontracting, pogingen tot coördinatie en coöptatie van staatswege en een civiele maatschappij die een gooi doet naar de politieke macht zijn allemaal situaties waarbij de autonomie en de kritische rol van de civiele maatschappij in vraag worden gesteld. Ten tweede spreekt de internationale consensus enkel over de formele relaties die leiden tot engagement tussen staat en civiele maatschappij. Zowel relaties die leiden tot disengagement - zowel formele als informele (zie 4.1 en 4.2), als relaties die leiden tot engagement, maar dan op een informele manier (zie 4.4), passen niet binnen het ideaal dat de internationale consensus vooropstelt.

\subsection{Informal Engagement}

\section{DE STAAT}

Informal engagement betekent hier dat de staat en de politieke elites hun informele netwerken aanspreken om toenadering te zoeken tot de civiele maatschappij. Zoals hierboven beschreven, probeert de staat via formele weg - via registratie, rapportering maar ook zelfopgezette 
NGO's en coöptatie - controle te verkrijgen over de civiele maatschappij. Net zoals bij processen van disengagement proberen de staat en de politieke elites dit ook via informele weg.

Via informele persoonlijke relaties trachten leden van de politieke elites greep te krijgen op NGO's en CSO's. In Kenia zijn er bijvoorbeeld pogingen ondernomen om Maendeleo ya Wanawake, een organisatie van vrouwengroepen, te incorporeren in de patroon-cliëntnetwerken van sommigen partijleiders (Bratton, 1989b: p. 579). De motieven van de politieke elites zijn niet enkel politiek, maar evenzeer economisch. Via deze NGO's krijgen politieke elites toegang tot nieuwe economische bronnen: de financiering van deze NGO's door westerse donoren en internationale NGO's. Politieke elites gebruiken deze nieuwe bronnen om hun patroon-cliënt-netwerken te onderhouden. Het opzetten van een eigen NGO (MONGO's of my own $N G O$ ) voor zelfverrijking en persoonlijke accumulatie is in dit opzicht eveneens een goed hulpmiddel (Nasong'o, 2002: p. 11).

Dit probleem wordt ook nog elite capture genoemd. Platteau (2003, 2004) beschrijft bijvoorbeeld de samenwerking tussen een internationale en een lokale NGO in een Sahel-land. (Zowel het land als de naam van de NGO worden niet vermeld.) De lokale NGO werd met steun van de INGO opgericht door een lokale leider. Na een tweetal jaar werd duidelijk dat de lokale leider financiële middelen van de NGO voor privé doeleinden had gebruikt. Wanneer de bevolking na het bekendmaken van dit probleem een nieuwe leider voor de NGO moest kiezen, werd dezelfde lokale leider verkozen. De verklaring van hun keuze lag bij hun loyaliteit voor hun leider. Hij werd beschouwd als diegene die de buitenlandse fondsen had aangetrokken. Aangezien dit voor iedereen een verbetering was, waren ze loyaal ten opzichte van hun 'patroon' en vonden het evident dat hun leider meer voordeel haalde uit het project dan de bevolking zelf. Chabal en Daloz (1999: p. 22) wijzen erop dat dit een structureel fenomeen is: "Indeed, NGOs are often nothing other than the new 'structures' with which Africans can seek to establish an instrumentally profitable position within the existing system of neo-patrimonialism."

Een andere vorm van informal engagement is de penetratie van politieke elites en staatsambtenaren in de parallelle informele netwerken die de civiele maatschappij heeft opgezet om aan de rovende staat te ontkomen. Hoewel bijvoorbeeld de informele eco- 
nomie voor de maatschappij een vorm van disengagement kan zijn, slaagt de staat er in om ook hier haar plunderende activiteiten voort te zetten. Meer nog, "The parallel-system structures could not be sustained without some measure of formal collusion" (Azarya \& Chazan, 1987: p. 123). Corruptie, fraude, verduistering en diefstal door overheidsambtenaren zijn dan ook kernactiviteiten in de informele economie. Ook via informele weg trachten de politieke elites hun macht te behouden. Lucratieve activiteiten opzetten in de informele economie is, net zoals de creatie van een eigen NGO, opnieuw een strategie om hun persoonlijke accumulatie en dus hun macht te vrijwaren (MacGaffey, 1994: p. 183). Wat in eerste instantie een exitstrategie van de bevolking is om aan de greep van de staat te ontkomen, blijkt in tweede instantie opnieuw de verticale netwerken bloot te leggen tussen de politieke elites en de bevolking, tussen high en low politics.

\section{De CiVIEle MaATSCHAPPIJ}

Informal engagement vanwege de civiele maatschappij kan op verschillende manieren tot stand komen. Net zoals politieke elites de civiele maatschappij infiltreren om hun politieke en economische macht te bestendigen, zullen andere actoren juist de civiele maatschappij infiltreren om die politieke macht te verkrijgen en dus een politieke carrière uit te bouwen: "A technocratic and professional class of middle-sectors that has been increasingly excluded from the prebends of predatory rule has found in the associational life of civil society the means to acquire status, power and money" (Fatton, 1995: p. 82).

Actoren uit de civiele maatschappij kloppen ook aan bij politieke patroons in hun zoektocht naar fondsen en meer invloed. Opnieuw zijn de informele verticale netwerken aan het werk. De Kivustreek in het begin van de jaren 1990 in het oosten van Congo, toen nog Zaïre, is hiervan een voorbeeld (Vlassenroot, 2004). In Zuid Kivu woedde er van 1993 tot en met 1995 een conflict tussen de leiders van de Bashien Warega-gemeenschappen. De aanleiding was onder andere de aanstelling van Faustin Birindwa, behorend tot de Bashi-gemeenschap, tot Eerste Minister onder het Mobutu-regime in maart 1993. Tot 1993 was de positie van de lokale, civiele maatschappij om geen steun te verlenen aan het regime van Mobutu. Dit veranderde wanneer 
Birindwa Eerste Minister werd. De groeperingen binnen de civiele maatschappij die afkomstig waren uit zijn streek en behoorden tot de Bashi gemeenschap sloten zich bij hem aan. Voor hen werden etnische en familiale banden voordeliger, want via Birindwa hoopten enkele leiders van de civiele maatschappij om hun macht te consolideren. Andere groeperingen binnen de civiele maatschappij beschouwden de aanstelling van Birindwa echter als een verraad tegenover de politieke oppositie. De aanstelling van Birindwa leidde bijgevolg tot een scheuring binnen de civiele maatschappij. Deze breuk was het gevolg van etnische loyaliteiten en persoonlijke netwerken. We kunnen bijgevolg vaststellen dat "the local network of autonomous associations was determined by the patron-client nature of existing social relations and, thus, would never go beyond the existing ethnic antagonisms" (Vlassenroot, 2004: p. 8).

Informal engagement van de civiele maatschappij kan via deze familiale en etnische loyaliteiten tevens meer gewelddadige vormen aannemen. De civiele maatschappij wordt op dat ogenblik een dekmantel voor etnisch en regionaal conflict, en geweld. Ikelegbe (2001) beschrijft de rol van de civiele maatschappij in het Niger Delta conflict in Nigeria. De Niger Delta regio vertegenwoordigt de belangrijkste bron van olie-inkomsten in Nigeria. In tegenstelling tot wat men kan verwachten, is de regio één van de armste en minst ontwikkelde van het land. Deze paradox leidde in het verleden al snel tot protest van de plaatselijke bevolking tegen de staat en de oliebedrijven. In het begin van de jaren 1990 ontstond er een sterk mobiliserend platform van civiele maatschappij organisaties die dit protest ondersteunden. Maar dit protest werd al snel vertaald in etnische en regionale termen. De Movement for the Survival of the Ogoni People (MOSOP) was één van de eerste organisaties die begin jaren 1990 hun protest vertaalden in een etnische agenda. Ook andere associaties en vooral jongerengroepen kregen na verloop van tijd een duidelijke etnische of separatistische agenda en schuwden gewelddadige confrontaties niet. De toestand werd nog moeilijker wanneer conflicten tussen de verschillende etnische groepen ontstonden. De verschillende organisaties van de Ijaw Youth Council (IYC) in de Niger Delta waren bijvoorbeeld betrokken bij gewelddadige confrontaties met zowel de staat als andere etnische groepen in de regio. Het Oduduwa Peoples Congres (OPC), vooral actief tussen 1993 en 1995, 
was dan weer gebaseerd op het Yoruba-nationalisme wat aanleiding gaf tot eisen van autonomie en effectief federalisme. Ook het OPC was betrokken bij etnische conflicten in de regio.

Wanneer Reno (1997a, 1997b, 2002) de context van falende staten beschrijft, verwijst hij naar krijgsheren die eveneens de civiele maatschappij gebruiken om hun machtsbasis uit te breiden of te versterken. Door zich te affiliëren met sociale of etnische groeperingen uit de lokale civiele maatschappij winnen krijgsheren de steun van de lokale bevolking. Op die manier kan een krijgsheer zijn aanwezigheid voorstellen als een legitieme strijd die de belangen van de bevolking verdedigt tegen een falende of corrupte staat. Maar de lokale civiele maatschappij heeft evenveel voordeel bij deze gang van zaken. In de context van een falende staat verliezen de patroons die deze staat op lokaal niveau vertegenwoordigen zowel hun politieke macht als hun greep op de aanwezige commerciële netwerken. Zich affiliëren met deze patroons levert dus minder economische voordelen op. Zowel de bevolking als de lokale civiele maatschappij die haar vertegenwoordigt, gaan op zoek naar nieuwe netwerken die economische voordelen kunnen opleveren. Krijgsheren spelen hier handig op in en worden door middel van geweld de nieuwe patroons van lokale netwerken die een diverse groep van actoren zoals sociale of etnische bewegingen/groeperingen, lokale en internationale privé bedrijven, rebellen, etc. met elkaar verbinden. Dit betekent opnieuw dat groeperingen van de civiele maatschappij ingeschakeld worden in gewelddadige conflicten.

Sommige auteurs, zoals Fatton (1995: p. 73), hebben dan ook een zeer sombere visie op de rol van de Afrikaanse civiele maatschappij: "It is the prime repository of "invented" ethnic hierarchies, conflicting class visions, patriarchal domination and irrenditist identities fueling deadly conflicts in many areas of the continent."

\section{CONCLUSIE}

De bedoeling van dit artikel was om een conceptueel kader te schetsen dat toelaat om de rol van de civiele maatschappij in Sub-SaharaAfrika te analyseren. Deze analyse kon niet gemaakt worden zonder te verwijzen naar de staat. De centrale vraag was bijgevolg hoe de staat en de civiele maatschappij zich tot elkaar verhouden. Om die vraag te 
beantwoorden brachten we twee centrale punten naar voren. Ten eerste werd aangetoond dat er een dynamische spanning bestaat tussen de staat en de civiele maatschappij in Sub-Sahara-Afrika. Deze dynamiek kwam aan bod wanneer we wezen op de relaties tussen staat en civiele maatschappij die eerder getuigen van engagement dan wel van disengagement. Ten tweede wezen we op het belang van informele naast formele relaties tussen de civiele maatschappij en de staat in de Afrikaanse context. Op basis van een literatuurstudie over de rol van de civiele maatschappij in Sub-Sahara-Afrika werd deze classificatie dan verder uitgewerkt. Een bijkomende vraag was of de verwachtingen die de internationale gemeenschap koestert omtrent de rol van de civiele maatschappij, en die gebaseerd zijn op het civiele maatschappij-paradigma, opgaan voor Sub-Sahara-Afrika.

Een eerste conclusie is dat de civiele maatschappij als een autonome tegenmacht of een waakhond ten opzichte van de staat een ideale, maar zeker niet altijd haalbare, situatie is in Sub-Sahara-Afrika. Zoals gezegd, de verschillende besproken interacties duiden op een dynamische spanning tussen staat en civiele maatschappij. Het optreden van de civiele maatschappij als een substituut voor de Afrikaanse staat in een land als Oeganda (Hearn, 2000) eind jaren tachtig heeft de legitimiteit van het regime - en het beleid van de financiële internationale instellingen - eerder versterkt dan in vraag gesteld. De civiele maatschappij kan ook niet worden beschouwd als een tegenmacht wanneer ze zelf een gooi doet naar de politieke macht, zoals het geval was in Zambia begin jaren 1990. Verder leidt het nieuwe partnership-model dat de Wereldbank propageert en waarbij de civiele maatschappij dient aan te kloppen bij de staat om contracten in de wacht te slepen tot vragen omtrent de autonomie van de civiele maatschappij. Kan een civiele maatschappij op een onafhankelijke manier het beleid van een land en dat van de Wereldbank beoordelen als ze financieel afhankelijk is van dat beleid? Daar komt bij dat ook via informele weg de autonomie van de civiele maatschappij in vraag wordt gesteld. Politieke elites infiltreren in de civiele maatschappij om hun macht te consolideren. Actoren binnen de civiele maatschappij zijn op hun beurt veelal afhankelijk van hun politieke patroons voor fondsen en invloed. Bijgevolg geldt op zijn minst dat de civiele maatschappij evenveel verweven is met de politieke macht dan dat ze er een autonome tegenmacht van vormt. 
Een tweede conclusie is dat het democratisch karakter van de civiele maatschappij geen vaststaand feit is. Het misbruiken van de civiele maatschappij voor persoonlijk economisch gewin is eerder een bewijs dat de elites zich hebben aangepast aan een veranderd internationaal klimaat van aid conditionality. De externe financiële bronnen die ze hierdoor verkrijgen, worden eerder gebruikt om hun patroon-cliëntnetwerken in stand te houden dan om een effectieve civiele maatschappij op te bouwen. Belangrijker is echter dat de civiele maatschappij eveneens gebruikt wordt voor andere, niet democratische, doeleinden. Organisaties en associaties binnen de civiele maatschappij kunnen dienen als dekmantel voor etnische of regionale agenda's. Er is zowel in het academische debat omtrent de rol van de civiele maatschappij in Sub-Sahara-Afrika als in het beleid van de internationale donoren te weinig aandacht besteed aan het feit dat een oncontroleerbare civiele maatschappij eveneens een oorzaak kan zijn van intense conflicten.

Een derde conclusie geeft een verklaring voor beide vorige vaststellingen. Indien men de rol van de civiele maatschappij in SubSahara-Afrika analyseert, kan men niet voorbij gaan aan de verticale patroon-cliënt-netwerken die bepalend zijn voor vele Afrikaanse maatschappijen. Deze netwerken verbinden de politieke elites met de rest van de bevolking en geven dus een verklaring voor de poreuze scheidingslijn tussen de civiele maatschappij en de politieke macht. Het lijkt er op dat de civiele maatschappij evenzeer ingeschakeld wordt in het bestaande systeem van patroon-cliënt-relaties, en dus evenveel bestaande machtsrelaties bestendigt dan ze in vraag stelt. In die zin is de civiele maatschappij een 'nieuwe' partner, die evenwel moeilijk los kan komen van het 'oude' systeem.

Maar onze analyse maakt evenzeer duidelijk dat de theorievorming die aanleiding gaf tot wat we het civiele maatschappij-paradigma noemden te eenzijdig en te optimistisch is. Te eenzijdig omdat ze uitgaat van een éénduidige relatie tussen staat en civiele maatschappij. Te optimistisch omdat er te weinig aandacht is voor het feit dat men een bloeiende civiele maatschappij ook voor niet-civiele doeleinden kan gebruiken. Beide theoretische veronderstellingen - de scheiding tussen staat en civiele maatschappij en de link tussen een sterke civiele maatschappij en democratie - zijn eerder normatief gefundeerd dan empirisch onderbouwd. We wezen erop dat deze scheiding tussen 
staat en civiele maatschappij alvast in Sub-Sahara-Afrika geen vaststaand feit is, en dit vooral door de informele relaties tussen de staat en de civiele maatschappij. In dit opzicht is een theoretisch kader dat uitgaat van een diversiteit aan mogelijke interacties tussen staat en civiele maatschappij, en dat naast formele ook informele interacties integreert, een beter uitgangspunt voor de analyse van de civiele maatschappij als een nieuwe actor voor politieke verandering.

\section{BIBLIOGRAFIE}

ANHEIER, H.K., \& CARLSON, L., 2002. "Civil Society: What it is, and how to measure it." Civil Society Briefing No 3. The Centre for Civil Society, London School of Economics and Political Science.

ARATO, A., 1981. "Civil Society against the State: Poland 1980-81". Telos 47.

ARATO, A., \& COHEN, J.L., 1992. Civil Society and Political Theory. Cambridge, Massachusetts, en London, England: MIT Press.

AZARYA, V., 1994. "Civil Society and Disengagement in Africa." In Civil Society and the State in Africa. ed. Harbeson, J.W., Rotchchild D., en Chazan N. Boulder, London: Lynne Rienner Publishers.

AZARYA, V., \& CHAZAN, N., 1987. "Disengagement from the State in Africa: Reflections on the Experience of Ghana and Guinea." Comparative Studies in Society and History, Vol. 29, No. 1, p. 106-131.

BAKER, G., 1998. "Civil Society and Democracy: The Gap Between Theory and Possibility." Politics, 18(2), p. 81-87.

BAYART, J-F. 1986. "Civil Society in Africa." In Political Domination in Africa. Reflections on the Limits of Power. ed. Chabal, P. Cambridge: Cambridge University Press.

BIALECKI, I., \& HEYNS, B., 1991. "Solidarnosc: Reluctant Vanguard or Makeshift Coalition?" The American Political Science Review, Vol. 85, No. 2, p. 351-370.

BRATTON, M., 1989a. "Beyond the State: Civil Society and Associational Life in Africa." World Politics, Vol. 41, No. 3 Apr., p. 407-430.

BRATTON, M., 1989b. "The Politics of Government-NGO Relations in Africa." World Development, Vol. 17, No. 4, p. 569-587.

BRATTON, M., \& van de WALLE, N., 1992. "Popular Protest and Political Reform in Africa." Comparative Politics, Vol. 24, No 4, p. 419-442.

BRATTON, M., \& van de WALLE, N. 1994. "Neopatrimonial Regimes and Political Transitions in Africa." World Politics, Vol. 46, No. 4, p. 453-489. 
BUTTERFIELD, J., \& WEIGLE, M.A., 1992. "Civil Society in Reforming Communist Regimes: The Logic of Emergence." Comparative Politics, Vol. 25, No 1, p. 1-23.

CHABAL, P. 1998. "A few considerations on democracy in Africa." International Affairs, 74: 2, p. 289-303.

CHABAL, P., \& DALOZ, J-P., 1999. Africa Works. Disorder as Political Instrument. Oxford, Bloomington: Indiana University Press.

CHAZAN, N., 1982. "The New Politics of Participation in Tropical Africa." Comparative Politics, Vol. 14, No. 2, Jan., p. 169-189.

CLAYTON, A., (ed.). 1997. Governance, democracy and conditionality. Oxford: INTRAC.

CROOK, R.C., 2001. "Strengthening democratic governance in conflict torn societies: civic organisations, democratic effectiveness and political conflict." IDS Working Paper 129. Brighton: Institute of Development Studies.

de TOCQUEVILLE, A., 1835/1840. Democracy in America. Chicago: University of Chicago Press.

DFID. 2006. Civil Society and Development. How DFID works in partnership with civil society to deliver the Millennium Development Goals. London.

DIAMOND, L. 1994. "Toward Democratic Consolidation." Journal of Democracy, Vol. 5. No 3, p. 4-17.

DOORNBOS, M., 1990. "The African State in Academic Debate: Retrospect and Prospect." The Journal of Modern African Studies, Vol. 28, No 2, p. 179-198.

EDWARDS, B., en FOLEY, M.W., 1996. "The Paradox of Civil Society." Journal of Democracy, Vol. 7, No 3, p. 38-52.

EDWARDS, M., en HULME, D., 1996. "Too Close for Comfort? The Impact of Official Aid on Nongovernmental Organization." World Development, Vol. 24, No 6, p. 961-973.

EUROPEAN COMMISSION. 2000. "ACP-EU Partnership Agreement signed in Cotonou on 23 June 2000." The Courier Special, September.

FATTON, R., 1992. Predatory rule. State and Civil Society in Africa. Boulder, London: Lynne Renner Publishers.

FATTON, R., 1995. "Africa in the Age of Democratization: The Civic Limitations of Civil Society." African Studies Review, Vol. 38, No. 2, p. 67-99.

FOWLER, A., 1991. "The role of NGOs in changing state-society relations: Perspectives from Eastern and Southern Africa." Development Policy Review, 9, p. 53-84. 
FOWLER, A., 2000. "Civil Society, NGDOs and Social Development: Changing the Rules of the Game." Geneva 2000 Occasional Paper No. 1. Geneva: United Nations Research Institute for Social Development.

FUKUYAMA, F., 1995. Trust: the social virtues and the creation of prosperity. New York: Free Press.

GALSTON, W.A., 1996. "Unsolved Mysteries: The Tocqueville Files. Won't You Be My Neighbour." American Prospect, Vol. 7, No 26.

GASPART, F., en PLATTEAU, J.P., 2003. "The Risk of Resource Misappropriation in Community-Driven Development." World Development, Vol. 31, No. 10, p. 16871703.

GIBSON, C.C., 2002. "Of Waves and Ripples: Democracy and Political Change in Africa in the 1990s." Annual Review of Political Science, Vol. 5. p. 201-221.

GLENN, J.K., 2001. Framing Democracy: Civil Society and Civic Movements in Eastern Europe. Stanford, CA: Stanford University Press.

GROOTAERT, C., NARAYAN, D., NYHAN JONES, V., \& WOOLCOCK, M., 2004. "Measuring Social Capital. An Integrated Questionnaire." World Bank Working Paper No 18. Washington D.C.: World Bank.

HANSEN, G., 1996. "Constituencies for Reform: Strategic Approaches for DonorSupported Civic Advocacy Groups." USAID Program and Operations Assessment Report No. 12, February, p. 13.

HARBESON, J.W., 1994. "Civil Society and Political Renaissance in Africa." In Civil Society and the State in Africa. ed. Harbeson, J.W., Rotchchild D., en Chazan N. Boulder, London: Lynne Rienner Publishers.

HARBESON, J.W., Rothchild, D, and Chazan, N., (ed.) 1994. Civil Society and the State in Africa. Boulder London, Lynne Rienner Publishers.

HEARN, J. 1999. "Foreign aid, democratisation and civil society in Africa: a study of South Africa, Ghana and Uganda." IDS Discussion Paper 368. Brighton: Institute of Development Studies.

HEARN, J., 2000. "Aiding Democracy? Donors and Civil Society in South Africa." Third World Quarterly, 21(5), p. 815-830.

HEARN, J., 2001. "The 'Uses and Abuses' of Civil Society in Africa." Review of African Political Economy, Vol. 28, No. 87, p. 43-53.

HELLIWELL, J.F., 2002. "OECD/ONS Conference on the Measurement of Social Capital. Rapporteur's Summary." September 25-27.

HIRSCHMAN, A.O., 1970. Exit, Voice, and Loyalty. Responses to Decline in Firms, Organizations, and States. Cambridge, Massachusetts: Harvard University Press.

HOWELL, J., \& PEARCE, J., 2001. Civil Society and Development. A Critical Exploration. Boulder, London: Lynne Rienner Publishers. 
HYDEN, G., 1997. "Civil Society, Social Capital, and Development: Dissection of a Complex Discourse." Studies in Comparative International Development, Vol. 32, No 1, p. 3-30.

IKELEGBE, A., 2001. "The perverse manifestation of civil society: evidence from Nigeria." The Journal of Modern African Studies, 39(1), p. 1-24.

KNACK, S., \& KEEFER, P., 1997. "Does Social Capital have an Economic Payoff? A Cross-Country Investigation." Quaterly Journal of Economics, 112(4), p. 12511288.

KUPERUS, T., 1999. "Building democracy: an examination of religious associations in South Africa and Zimbabwe." The Journal of Modern African Studies, 37(4), p. 643-668.

LANDOLT, P., \& PORTES, A., 1996. "Unsolved Mysteries: The Tocqueville Files. The downside of Social Capital." American Prospect, Vol. 7, No 26.

LARMER, M., 2006. "'The Hour Has Come at the Pit': The Mineworkers' Union of Zambia and the Movement for Multi-Party Democracy, 1982-1991." Journal of Southern African Studies, Volume 32, No 2, p. 293-312.

LEMARCHAND, R., 1992. "Uncivil States and Civil Societies: How Illusion Became Reality." The Journal of Modern African Studies, Vol. 30, No. 2, p. 177-192.

LOVELL, D.W., 1999. "Nationalism, Civil Society, and the Prospects for Freedom in Eastern Europe." Australian Journal of Politics and History, Vol. 45, No 1, p. 65-77.

MACGAFFEY, J., 1994. "Civil Society in Zaïre: Hidden Resistance and the Use of Personal Ties in Class Struggle." In Civil Society and the State in Africa. ed. Harbeson, J.W., Rotchchild D., en Chazan N. Boulder, London: Lynne Rienner Publishers.

MAKUMBE, J.Mw., 1998. "Is there a civil society in Africa?" International Affairs, Vol. 74, No 2, p. 305-317.

MCGEE, R., 2003. "Poverty Reduction Strategy Papers: A Role for Civil Society." In Development Planning and Poverty Reduction. ed. Potts, D., Ryan, P., en Toner, A. Hampshire: Palgrave MacMillan.

MERCER, C., 2002. "NGOs, civil society and democratization: a critical review of the literature." Progress in Development Studies, 2,1, p. 5-22.

MONGA, C., 1995. "Civil Society and Democratisation in Francophone Africa." The Journal of Modern African Studies, Vol. 33, No 3, p. 359-379.

NARAYAN, D., 1997. "Voices of the Poor. Poverty and Social Capital in Tanzania." Environmentally and socially sustainable development studies and monographs series 20. Washington D.C.: World bank.

NASONG'O, S.W., 2002. "Civil Society and African Democratization: The Flip Side of the Coin." Studies of Democratization, Vol. 1, Fall 2002, p. 16. 
NDEGWA, S.N., 1994. "Civil Society and Political Change in Africa. The Case of Non-Governmental Organizations in Kenya." International Journal of Commonwealth Studies, Vol. XXXV, No. 1-2, p. 19-36.

ORVIS, S., 2001. "Civil Society in Africa of African Civil Society?" Journal of Asian and African Studies, 36(1), p. 17-38.

PIETRYK, D.I., 2003. "Democracy or Civil Society." Politics, Vol. 23(1), p. 38-45.

PlATTEAU, J.P., 2004. "Monitoring Elite Capture in Community-Driven Development." Development and Change, 35(2), p. 223-246.

PUTNAM, R., 1993. Making Democracy Work. Civic Traditions in Italy. Princeton, New Jersey: Princeton University Press.

PUTNAM, R., 1995. "Tuning in, Tuning out. The strange disappearance of social capital in America." Political Science and Politics, Vol. 28, No 4. Dec., p. 664-683.

PUTNAM, R., 1996a. "The Strange Disappearance of Civic America." American Prospect, Vol. 7, No 24.

PUTNAM, R., 1996b. "Unsolved Mysteries: The Tocqueville Files. Robert Putnam Responds." American Prospect, Vol. 7, No 25.

PUTNAM, R., 2000. Bowling Alone: The Collapse and Revival of American Community. New York: Simon \& Schuster.

RAU, Z., (ed.) 1991. The Reemergence of Civil Society in Eastern Europe and the Sovjet Union. Boulder: Westview Press.

RENO, W., 1997a. "African Weak States and Commercial Alliances." African Affairs, Vol. 96, No 383, p. 165-185.

RENO, W., 1997b. "War, Markets, and the Reconfiguration of West Africa's Weak States." Comparative Politics, Vol. 29, No 4, p. 493-510.

RENO, W., 2002. "The Politics of Insurgency in Collapsing States." Development and Change, 33(5), p. 837-858.

SCHUDSON, M., 1996. "Unsolved Mysteries: The Tocqueville Files. What if Civic Life Didn't Die?" American Prospect, Vol. 7, No 25.

SCOTT, J.C., 1987. Weapons of the weak: everyday forms of peasant resistance. New haven (Conn.) : Yale University Press.

SKOCPOL, T., 1996. "Unsolved Mysteries: The Tocqueville Files. Unravelling From Above." American Prospect, Vol. 7. No 25.

THOMSON, A., 2000. An Introduction to African Politics. London, New York: Routledge.

TVEDT, T., 1998. Angels of Mercy or Development Diplomats? NGOs \& Foreign Aid. Oxford: James Curey Ltd and Trenton: Africa World Press. 
UNDP. 2003. Partners in Human Development: UNDP and Civil Society. New York.

VALELLY, R., 1996. "Unsolved Mysteries: The Tocqueville Files. Couch-Potato Democracy?" American Prospect, Vol. 7, No 25.

VAN ROOY, A., 1998. Civil Society and the Aid Industry. London and Sterling: Earthscan Publications Ltd.

VLASSENROOT, K., 2004. "The Illusion of Resistance: Civil Society in the Democratic Republic of Congo." Paper presented at the Conference 'Zivilgesellschaft. Chancen und Grenzen eines Sozialwissenschaftlich-Philosophischen Konzepts', Politische Akademie Tutzing, Germany, 6-9 May.

VONDOEPP, P., 1996. "Political Transition and Civil Society: The Cases of Kenya and Zambia." Studies in Comparative International Development, Vol. 31, No. 1, p. 24-47.

WEBER, M., 1964. The theory of social and economic organization. Edited with an introduction by Talcott Parsons. New York: Free Press.

WERELD BANK. 2001. World Development Report 2000/2001. New York: Oxford University Press.

WILLIAMS, D., en Young, T., 1994. "Governance, the World Bank and Liberal Theory." Political Studies, XLII, p. 84-100.

WOODS, D., 1992. "Civil Society in Europe and Africa: Limiting State Power through a Public Sphere." African Studies Review, Vol. 35, No. 2, p. 77-100.

WORLD BANK. 1989. Sub-Saharan Africa. From Crisis to Sustainable Growth. A Long-Term Perspective Study. Washington D.C.

WORLD BANK. 2005. World Bank - Civil Society Engagement. Review of Fiscal Years 2002-2004. Washington D.C. 